\title{
ANALISIS VEGETASI STRATA SEMAK DI PLAWANGAN TAMAN NASIONAL GUNUNG MERAPI PASCA ERUPSI MERAPI 2010
}

\author{
Dyna Natalia, Trikinasih Handayani
}

\begin{abstract}
ABSTRAK
$\mathrm{P}$ enelitian ini bertujuan untuk mengetahui jenis-jenis vegetasi strata semak yang memiliki peranan paling besar berdasarkan Indeks Nilai Pentingnya, Indeks diversitas jenis strata semak dan pengaruh lingkungan abiotik yang meliputi (suhu udara, suhu tanah, kelembaban udara, $\mathrm{pH}$ tanah, kandungan besi (Fe), kadar silika (Si), kadar mangan (Mn) dan kapasitas pertukaran kation (KPK) dalam tanah) yang terdapat di daerah Plawangan Taman Nasional Gunung Merapi Yogyakarta.

Pada penelitian ini digunakan tiga area kajian yaitu area kajian A (dekat dengan erupsi merapi), area kajian B (agak jauh dengan erupsi merapi) dan area kajian C (jauh dengan erupsi merapi). Adapun metode yang digunakan adalah metode Point Centered Quarter (PCQ). Analisis data yang digunakan untuk mengetahui pola pengelompokan stand vegetasi strata semak terhadap faktor abiotik yang terukur adalah cluster dengan menggunakan program SPSS versi 16.

Berdasarkan hasil penelitian di Palawangan Taman Nasional Gunung Merapi Yogyakarta diperoleh 12 jenis vegetasi strata semak. Vegetasi strata semak yang memiliki rerata INP tertinggi pada area kajian A (dekat dengan erupsi merapi) yaitu Chromolaena odorata (80.0714\%), Eupatorium riparium (41.77775\%), dan Crotalaria striata (33.84885\%). Area kajian B (agak jauh dengan erupsi merapi) yaitu Chromolaena odorata (82.1701\%), Lantana camara (55.68935\%), dan Eupatorium riparium (51.53475\%). Dan pada area kajian C (jauh dengan erupsi merapi) yaitu Chromolaena odorata (78.4494\%), Bambusa Sp (61.029\%), dan Clidemia hirta D.Don. (35.8157\%). Rerata Indeks Diversitas pada Area kajian A (1.73), area kajian B (1.64) dan Area kajian C (1.7). Faktor lingkungan abiotik yang berpengaruh terhadap pola pengelompokan stand vegetasi strata semak adalah Si, Fe dan Mn. Adapun kelembapan udara, suhu udara, suhu tanah, $\mathrm{pH}$ tanah, KPK tanah merupakan faktor abiotik yang tidak mempengaruhi pola pengelompokan stand. Melalui metode pengkajian, hasil penelitian yang


dilakukuan di daerah Plawangan Taman Nasional Gunung Merapi Yogyakarta dapat digunakan sebagai alternatif sumber belajar Biologi siswa SMA kelas X pada materi pembelajaran struktur dan fungsi ekosistem terestrial dalam bentuk CD pembelajaran.

Kata kunci: Analisis vegetasi, Strata semak, Plawangan Taman Nasional Gunung Merapi 


\section{PENDAHULUAN}

Taman Nasional Gunung Merapi (TNGM) merupakan kawasan pelestarian alam yang memiliki ekosistem asli berupa perpaduan ekosistem gunung berapi dengan hutan dataran tinggi dan pegunungan yang dikelola dengan sistem zonasi dan dimanfaatkan untuk tujuan penelitian, ilmu pengetahuan, pendidikan, menunjang budidaya, pariwisata dan rekreasi. Penunjukan Kawasan Hutan Gunung Merapi sebagai Taman Nasional Gunung Merapi sesuai dengan Surat Keputusan Menteri Kehutanan No. 134/ Menhut-II/2004 pada tanggal 4 Mei 2004 tentang perubahan Fungsi Kawasan Hutan Lindung, Cagar Alam dan Taman Wisata Alam. Hutan Gunung Merapi seluas \pm 6.410 ha, yang terletak di Kabupaten Magelang, Boyolali, Klaten Provinsi Jawa Tengah serta Kabupaten Sleman, Provinsi Daerah Istimewa Yogyakarta (Susantyo, 2011).

Menurut Arif (Indriyanto, 2010) Hutan merupakan suatu wilayah yang memiliki banyak tumbuh-tumbuhan lebat yang berisi antara lain pohon, semak, paku-pakuan, rumput, jamur dan lain sebagainya serta menempati daerah yang cukup luas. Hutan memiliki manfaat yang besar bagi kehidupan manusia. Menurut Undang-undang Nomor 41 Tahun 1999 Pasal 1 Ayat (1) tentang kehutanan, Hutan adalah satu kesatuan ekosistem berupa hamparan lahan berisi sumber daya alam hayati yang didominasi oleh semak dalam persekutuan lingkungan dimana komponen yang satu dengan yang lainnya tidak dapat dipisahkan.

Ekosistem adalah hubungan antara kumpulan beberapa populasi disuatu tempat yang mengadakan interaksi, baik secara langsung maupun tidak langsung dengan lingkungan abiotik dan hubungannya adalah timbal balik. Ekosistem hutan adalah hubungan antara kumpulan beberapa populasi baik itu binatang dan tumbuh-tumbuhan yang hidup dalam lapisan dan dipermukaan tanah dan terletak pada suatu kawasan serta membentuk suatu kesatuan ekosistem yang berada dalam keseimbangan yang dinamis yang mengadakan interaksi baik secara langsung maupun tidak langsung dengan lingkungannya dan antara satu dan yang lainnya tidak dapat dipisahkan (Soemarwoto, 1986).

Suatu ekosistem dapat mengalami kerusakan yang disebabkan oleh letusan gunung merapi, tanah longsor, penambangan batu bara maupun disebabkan oleh ulah manusia seperti pembakaran hutan dan penggundulan hutan yang menyebabkan perubahan pada ekosistem baik sebagian maupun keseluruhan yang diikuti perubahan jenis dan jumlah vegetasi pada daerah tersebut. Terjadinya awan panas pada 26 Oktober 2010 sebagian besar materialnya telah mengisi lembah sungai yang ada di sekitar Gunung Merapi dan beberapa lahan pada daerah-dae- 
rah yang berdekatan dengan Gunung Merapi mengalami kerusakan (Dephut, 2010).

Kerusakan lahan akibat awan panas dan erupsi material Gunung Merapi mengenai berbagai jenis lahan. Lahan-lahan yang terkena diantaranya adalah kawasan Hutan Plwangan Taman Nasional Gunung merapi Yogyakarta. Hutan plawangan merupakan wilayah yang mengalami kerusakan sedang. kerusakan sedang tejadi karena adanya awan panas dan lahar panas yang melewati kali kuning dimana area ini berdekatan dengan area penelitian.

Berdasarkan survei pendahuluan di lapangan, daerah Plawangan merupakan daerah dengan kriteria kerusakan sedang akibat erupsi Gunung Merapi pada tahun 2010. Kriteria kerusakan tersebut membuat kawasan tersebut tidak kehilangan banyak vegetasi. Menurut Dephut (2010) peristiwa letusan Gunung Merapi akhir 2010, pebagian kawasan berdasarkan kategori kerusakan fisik dapat dibedakan sebagai berikut : (1) rusak berat: vegetasi rusak total hingga tidak mensisakan bagian sedikitpun (2) rusak sedang: vegetasi masih tersisa namun kondisinya rusak, mensisakan tonggak-tonggak yang kering (3) rusak ringan: vegetasi masih hidup, relatif utuh, namun tertutup abu vulkanik.

Penelitian ini dilakukan di kawasan Plawangan Taman Nasional gunung Merapi untuk mengetahui indeks nilai penting (INP) dan indeks diversitas (ID) strata semak yang terdapat di kawasan tersebut pasca erupsi gunung merapi. Parameter dalam penelitian ini meliputi dominansi, dominansi relative, frekuensi, frekuensi relative, INP, dan ID. Lingkungan abiotik yang diukur meliputi: suhu udara, suhu tanah, $\mathrm{pH}$ tanah, kelembaban udara, kandungan Fe, kadar Si, kadar Mn, dan KPK. Penelitian ini digunakan sebagai alternative sumber belajar biologi siswa SMA pada materi pembelajaran struktur dan fungsi ekosistem terrestrial.

\section{METODE}

Penelitian ini dilaksanakan di Hutan Plawangan Taman Nasional Gunung Merapi Yogyakarta, dengan menggunakan metode Point Centered Quarter. Metode Poin Centered Quarter adalah metode pengukuran jarak yang dilakukan dari titik sampling ketanaman (semak) terdekat dalam tiap quarter atau kuadran, setiap titik sampling dihasilkan empat pengukuran (Handayani, 2010).

Parameter vegetasi yang digunakan untuk mengetahui peranan jenis semak di Kawasan Plawangan Taman Nasional Gunung Merapi Yogyakarta, adalah Indeks Nilai Penting (INP). Untuk mengetahui peranan jenis semak pada suatu area tertentu, diperoleh dari densitas, densitas relatif, dominansi, dominansi relatif, frekuensi, frekuensi relatif. Rumus yang di gunakan adalah sebagai berikut: Mueller Dombois (Handayani, 2010). 
$\begin{array}{ll}\text { Rata-rata jarak (D) } & =\frac{\text { total jarak }}{4 \mathrm{x} \text { jumlah titik sampling }} \\ \text { Densitas multak (DT) } & \left.=\frac{\text { unit area }}{(\text { rata-rata jarak })^{2}}=\text { unit area/(D) }\right)^{2}\end{array}$

Parameter vegetasi terdiri atas:

1) Densitas tiap spesies $=\frac{(\text { Total jenis i })}{(4 \times \text { Jumlah titik sampling })} \times$ Densitas mutlak

2) Densitas Relatif $($ KRi $)=\frac{(\text { Densitas i })}{(\text { Densitas mutlak })} \times 100 \%$

3) Frekuensi $\quad=\frac{\text { Jumlah titik sampling yang terdapat jenis }}{\text { Jumlah titik sampling }}$

4) Frekuensi Relatif $(\mathrm{FRi})=\frac{\text { Frekuensi }}{\text { Total frekuensi }} \times 100 \%$

5) Dominansi = = Rata-rata basal area jenis $\times$ densitas

6) Dominansi Relatif (DRI) $=\frac{\text { Dominansi }}{\text { Total dominansi }} 100 \%$

7) $\mathrm{INP}=$ Densitas relative + Dominansi relative + Frekuensi relative

Perhitungan indeks diversitas dapat dihitung menurut Shannon Wiener (Odum, 1996) yaitu:

$H^{\prime}=-\Sigma\left(\frac{n i}{N}\right) \log \left(\frac{n i}{N}\right)$

$H^{\prime}=-\Sigma p i \log p i$

Keterangan :

$n i=$ nilai kepentingan untuk tiap spesies

$N=$ nilai kepentingan total

$p i=$ peluang kepentingan untuk tiap spesies $=\frac{n i}{N}$ 
Untuk mengetahui hubungan antara pola vegetasi strata semak dengan faktor lingkungan abiotik yang terukur (kelembaban udara, suhu tanah, suhu udara, $\mathrm{pH}$ tanah, Si, kpk, kandungan Fe di dalam tanah) digunakan metode cluster (Arrijani, 2006). Metode cluster yang digunakan dihitung dengan computer dengan menggunakan program SPSS versi 16.

Analisis cluster merupakan teknik mereduksi informasi. Informasi dari sejumlah objek akan direduksi menjadi sejumlah kelompok, dimana jumlah kelompok lebih kecil dari jumlah objek. Objek-objek yang sama dikelompokkan dalam suatu kelompok sehingga mempunyai tingkat kesamaan yang tinggi dibandingkan dengan objek dari kelompok lain. Tujuan utama teknik ini adalah melakukan pengelompokkan berdasarkan kriteria tertentu sehingga objekobjek tersebut mempunyai variasi di dalam cluster (within cluster) relatif kecil dibandingkan variasi antar cluster (between cluster) (Sakura, 2008).

\section{CARA KERJA}

1. Observasi pendahuluan untuk menentukan batas-batas area kajian yang terkena dampak letusan Gunung Merapi dengan menggunakan peta lokasi berskala 1: 25.000. Diketahui luas wilayah yang terkena dampak letusan Gunung Merapi atau rusak digunakan untuk penelitian seluas 119,5 Ha.

2. Ditentukan 3 area kajian yaitu area kajian A, area kajian B, C. Dengan jarak antar area kajian $500 \mathrm{~m}$. Masing-masing area kajian mempunyai luas $39.500 \mathrm{~m}^{\wedge} 2$.

3. Pada setiap area kajian dibuat 20 stand, yaitu Area kajian A(dekat dengan erupsi merapi) stand 1-20, Area kajian B (agak jaug dengan erupsi merapi) stand 21-40 dan Area kajian C (jauh dengan erupsi merapi) stand 41-60 yang masing-masing stand mempunyai luas $1.975 \mathrm{~m}^{\wedge} 2$. Dengan panjang $100 \mathrm{~m}$ dan lebar 19,75m.

4. Dibuat garis transek utama sepanjang $100 \mathrm{~m}$, kemudian dibuat garis sub transek yang memotong garis transek utama yang berjarak masing-masing 19,75 m. Jarak antar garis sub transek $10 \mathrm{~m}$.

5. Diukur keliling dari spesies strata semak dengan cara mengukur batang yang tepat berada dipermukaan tanah.

6. Hasil pengidentifikasian dan pengukuran di masukkan kedalam tabel pengamatan.

7. Jenis-jenis vegetasi strata semak yang telah diketahui nama spesiesnya, di identifikasi langsung di tempat penelitian. Spesies yang belum diketahui nama spesiesnya dilakukan identifikasi dengan cara menggunakan kunci determinasi atau mencocokkan spesies dengan Atlas Tumbuhan Obat Indonesia (Dalimartha, 2003) dan internet (http://www. plantamor.com), dibuat herbarium untuk 
diidentifikasi di laboratorium biologi UAD. Adapun buku yang menjadi acuan adalah stenis (1992) dan Weeds of Rice in Indonesia (1987).

8. Mengukur faktor lingkungan pada masing-masing stand sebayak 3 kali pengulangan yang meliputi suhu tanah, suhu udara, kelembaban udara, $\mathrm{pH}$ tanah, kandungan besi (Fe), kadar mangan (Mn) dan kadar silika (Si) didalam tanah pada tiap-tiap area kajian. Untuk mengetahui kandungan unsur tersebut, diambil sampel tanah sebanyak 3 pada masing-masing area kajian yang terkena erupsi Gunung Merapi untuk selanjutnya di analisis di Balai Penelitian Tanah Yogyakarta, sedangkan pengukuran kapasitas pertukaran kation (KPK) di analisis di Fakultas Pertanian UGM.

\section{HASIL DAN PEMBAHASAN}

Indeks Nilai Penting Jenis Strata Semak Pada Area kajian A.
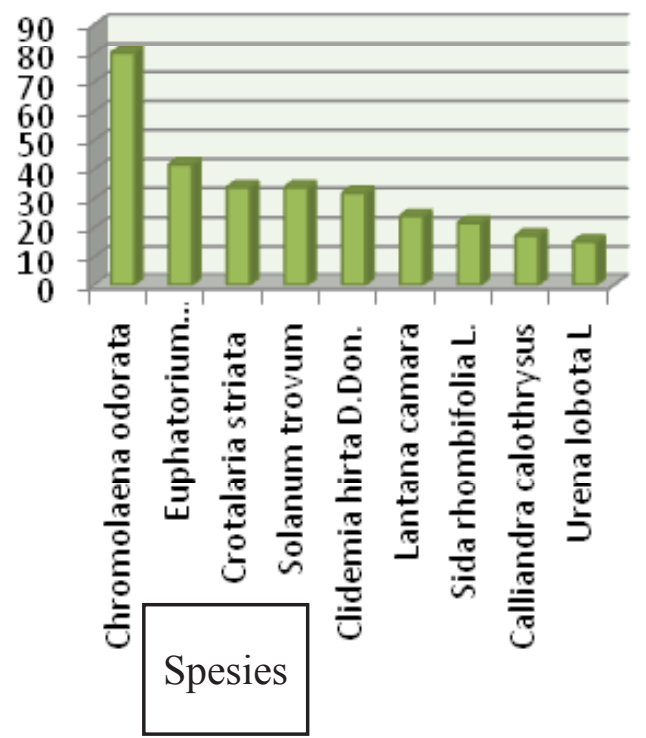

JURNAL BIOEDUKATIKA

\section{Gambar 1. Grafik rerata INP strata se- mak pada area kajian $A$}

Berdasarkan hasil pengamatan, dapat dilihat bahwa pada area kajian A (stand 120) dapat dijumpai sebanyak 9 jenis vegetasi strata semak yang memiliki rerata INP tertinggi berturut-turut yaitu Chromolaena odorata dengan rerata INP (80.0714\%), Euphatorium riparium dengan rerata INP (41.77775\%) dan Crotalaria striata dengan rerata INP (33.84885\%). Jenis semak dengan rerata INP terendah adalah Sida rhombifolia L. dengan rerata INP (21.63815\%), Calliandra calothrysus (17.34655\%) dan Urena lobata L. rerata INP (15.7125\%).

Struktur dan komposisi jenis vegetasi strata semak yang terdapat di area kajian B

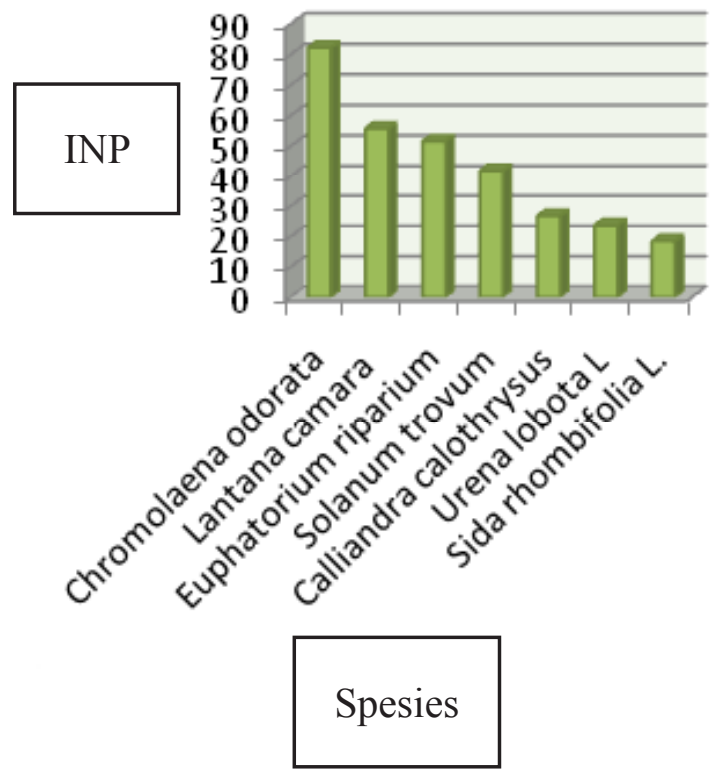

Gambar 2. Grafik rerata INP strata semak pada area kajian $B$

VOL. 1 NO. 1 JULI 2013 HAL. 1 - 96 
Berdasarkan hasil pengamatan, dapat dilihat bahwa pada area kajian B (stand 2140) dapat dijumpai sebanyak sebanyak 7 jenis vegetasi strata semak. Tiga spesies yang memiliki rerata INP tertinggi berturut-turut yaitu Chromolaena odorata dengan rerata INP (82,1701\%), Lantana camara dengan rerata INP (55.68935\% ) dan Euphatorium riparium dengan.rerata INP (51.53475\%). Jenis semak dengan rerata INP terendah adalah Calliandra calothrysus dengan rerata INP (26.68045 \%), Urena lobota L. dengan rerata INP (23\%.6055), dan Sida rhombifolia L. dengan rerata INP (18.46795\%).

Struktur dan komposisi jenis vegetasi strata semak yang terdapat di area kajian C dapat dilihat pada Tabel 3. dan Gambar 6.

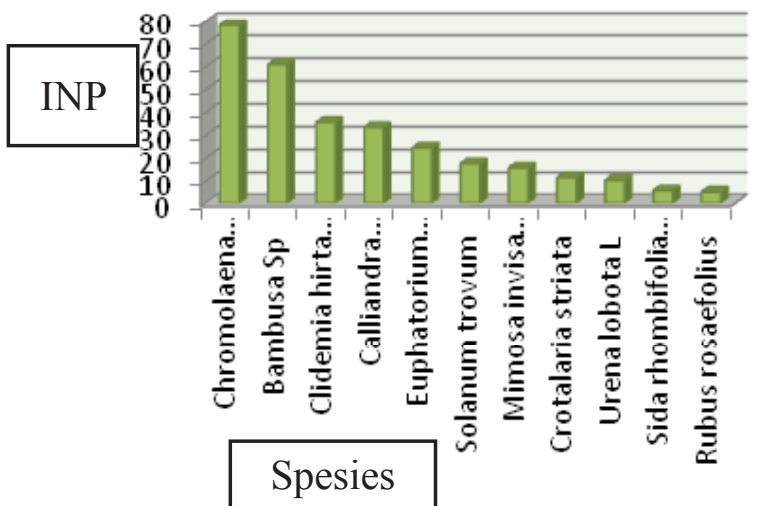

\section{Gambar 3. Grafik rerata INP strata se- mak pada kajian $\mathrm{C}$}

Dari hasil penelitian yang telah dilakukan pada area Kajian C (di stand 41-60) diperoleh 11 spesies dengan 3 spesies yang memiliki rerata INP tertinggi berturut-turut yaitu, Chromolaena odorata dengan rerata INP (78.4494\%), Bambusa Sp dengan rerata
INP (61.029\%), dan Clidemia hirta D.Don. dengan rerata INP (35.8157\%). Sedangkan 3 spesies yang memiliki rerata INP terendah yaitu Urena lobata L. dengan rerata INP (10.50875\%), Sida rhombifolia L. dengan rerata INP (5.5413\%), dan Rubus rosaefolius dengan Rerata INP (4.92885 \%).

\section{INDEKS DIVERSITAS (H')}

Indeks diversitas merupakan parameter vegetasi yang sangat berguna untuk membandingkan berbagai komunitas tumbuhan, terutama untuk mempelajari pengaruh gangguan faktor-faktor lingkungan atau abiotik terhadap komunitas. Keanekaragaman jenis yang terdapat dalam komunitas dapat diketahui dari Indeks diversitas (Fachrul, 2007). Rerata indeks diversitas pada seluruh area kajian disajikan pada grafik dibawah ini.

Besarnya Indeks Diversitas masingmasing stand pada tiap area kajian yaitu area kajian A, area kajian B dan area kajian C. Dari ketiga area kajian tersebut, area kajian A merupakan daerah yang mempunyai rerata Indeks Diversitas sebesar 1.73. Adapun pada area kajian B mempunyai rerata Indeks Diversitas terreandah sebesar 1.64. Di daerah ini keadaan hutannya masih rusak belum banyak tanaman yang tumbuh sehingga keanekaragaman tumbuhannya masih sedikit.

Pada area kajian $\mathrm{C}$ mempunyai rerata Indeks Diversitas sebesar 1.7. Di daerah ini keadaannya sudah cukup baik, sudah banyak 
tanaman yang tumbuh sehingga terdapat keanekaragaman tumbuhannya.

Adapun lampiran 6. dan Gambar 9. juga dapat dilihat dari ketiga area kajian penelitian, pada area kajian B mempunyai rerata Indeks Diversitas terendah dibandingkan dengan area kajian A dan area kajian C. Area kajian B mempunyai rerata Indeks Diversitas yaitu sebesar 1.64. Hal ini disebabkan karena pada area kajian B merupakan daerah rusak yang langsung terkena erupsi merapi pada tahun 2010. Di daerah ini keadaannya masih gundul belum banyak tanaman yang tumbuh.

Menurut Shannon-Wiener (Fachrul, 2007) jika nilai H'> 3 menunjukkan bahwa keanekaragaman spesies pada suatu transek adalah melimpah tinggi, sedangkan jika H' $1 \leq \mathrm{H}^{\prime} \leq 3$ menunjukkan bahwa keanekaragaman spesies pada suatu transek adalah sedang melimpah. Dari data diatas dapat disimpulkan bahwa pada ketiga area kajian memiliki keanekaragaman spesies yang sedang.

Dari hasil analisis cluster menunjukkkan bahwa faktor abiotik yang tidak berpengaruh terhadap pola pengelompokan stand adalah kelembaban udara 0.294, suhu udara 0.984, suhu tanah 0.371, pH tanah 0.810, KPK (kapasitas pertukaran kation) 0.965, Sedangkan factor abiotik yang berpengaruh terhadap pola pengelompokan stand yaitu, Si (silika) 0.000, Fe (besi) 0.000 dan $\mathrm{Mn}$ (mangan) 0.000 .

\section{KESIMPULAN}

Berdasarkan hasil penelitian dan pembahasan dapat disimpulkan sebagai berikut:

1. Chromolaena odorata merupakan jenis vegetasi strata semak yang mempunyai peranan paling besar berdasarkan Indeks Nilai Pentingnya. yaitu Chromolaena odorata terletak pada area kajian A sebesar 80.0714\% dan pada area kajian B sebesar 82.1701\% dan Chromolaena odorata pada area kajian C sebesar 78.4494\%.

2. Rerata Indeks Diversitas jenis vegetasi strata semak pada ke tiga area kajian yaitu pada area kajain A mempunyai rerata H' sebesar 1.73 dan pada area kajian B memiliki rerata H' sebesar 1.64 sedangkan pada area kajian $\mathrm{C}$ memiliki rerata $H^{\prime}$ sebesar 1.7

3. Berdasarkan uji analisis clutser dapat digolongkan menjadi 2 yaitu clutser 1 dan clutser 2. Pengelompokan stand dipengaruhi oleh faktor abiotik $\mathrm{Si}, \mathrm{Fe}$, dan $\mathrm{Mn}$, adapun kelembaban udara, suhu udara, suhu tanah KPK, dan $\mathrm{pH}$ tanah tidak berpengaruh terhadap pola pengelompokan stand. Berdasarkan uji analisis cluster diperoleh 2 cluster yaitu cluster 1 dan cluster 2 . 


\section{DAFTAR PUSTAKA}

Arrijani, 2006. “Analisis Vegetasi Hulu DAS Cianjur Taman Nasional Gunung Gede Pangrango”. Biodiversitas. Vol. 7. No. 2. Halaman: 147-153. Kampus Universitas Negeri Manado. biodiversitas.mipa.uns.ac.id/D/D0702/ D070212.pdf di akses pada tanggal 03 April 2012.

Departemen Kehutanan. 2011. Survei kondisi Tumbuhan dan Satwa Liar Taman Nasional Gunung Merapi Pasca Erupsi Tahun 2010. Yogyakarta : DIPA BA 029 BALAI TAMAN NASIONAL GUNUNG MERAPI TA. 2011.

Fachrul, M, F. 2007. Teknik Sampling Bioekologi. Jakarta: BumiAksara.

Handayani, T .2010 . Hand Out Ekologi. Program Study Pendidikan Biologi. JPMIPA. Yogyakarta : Universitas Ahmad Dahlan.

Indriyanto, 2010. Ekologi Hutan. Jakarta : Bumi Aksara.

Sakura, 2008. Analisis Cluster. http://one. indoskripsi.com/judul-skripsi-tugasmakalah/tugas-kuliah-lainnya/analisis-cluster. 